\title{
Leading Change in the System of Scholarly Communication: A Case Study of Engaging Liaison Librarians for Outreach to Faculty
}

\author{
Kara J. Malenfant
}

This narrative, single-case study examines how liaison librarians at the University of Minnesota (UMN) came to include advocating for reform of the scholarly communication system among their core responsibilities. While other libraries may hire a coordinator or rely on a committee to undertake outreach programs, UMN has defined baseline expertise in scholarly communication for all librarians who serve as liaisons to disciplinary faculty members. By "mainstreaming" scholarly communication duties, UMN is declaring these issues central to the profession. ${ }^{1}$ This intrinsic study uses evidence gathered from open-ended interviews with three participants, supplemented by documentation. It explores the context of these changes, systems thinking, and new mental models.

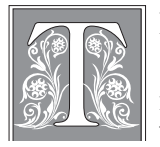

he formal system of scholarly communication - which allows research and other scholarly writings to be created, evaluated, registered, disseminated, and preserved ${ }^{2}$ - is rapidly evolving. Libraries and universities are both responding to this dynamic environment and seeking to influence its development. ${ }^{3}$

Some academic libraries purposefully target key stakeholders on campus-faculty authors, researchers, and administrators. They plan outreach programs and education initiatives, being deliberate about the ways they seek to influence change on their campuses. They commit resources toward these efforts to ensure sustainability. The initial stages of a library-led scholarly communication outreach program often include educating librarians on the issues and training them in techniques to be effective advocates. Engaging library staff to carry out the various components of the outreach program plan is a key element to its success.

Changes in scholarly communication are forcing librarians to shift their mental models and alter their services. This requires substantial personal and organizational commitment to change. As the Scholarly Communications and Government Relations

Kara J. Malenfant is Scholarly Communications and Government Relations Specialist at the Association of College and Research Libraries and a Ph.D. student in the Leadership and Change program at Antioch University; e-mail kmalenfant@ala.org. She would like to thank Karla Hahn and David Free for their comments on earlier drafts of this article. (CKara J. Malenfant 
Specialist at the Association of College and Research Libraries (ACRL), a division of the American Library Association, I have a strong personal and professional interest in understanding how this kind of change occurs. I want to understand the change process and how different individuals' leadership, both positional and without authority, plays into this kind of change.

\section{Choice of Case}

In this narrative, single-case study, I aim to develop an understanding of ways liaison librarians at the University of Minnesota (UMN) became engaged in furthering the goals of the outreach program and how they view these changes in their work. This case looks closely at one organization that has been intentionally implementing a change process and integrating scholarly communication activities into the work life of liaison librarians. Incorporating new roles and new thinking into a complex system is always dependent on the local situation, the larger environmental shifts, and the interconnected nature of the changes. I hope to gain a better understanding of the leadership principles that foster participation in this change effort and a sense of which elements may be transferrable.

By "mainstreaming" scholarly communication duties into the work of all liaison librarians, the UMN Libraries are moving these issues to the very center of the profession and fully owning them. ${ }^{4}$ I selected UMN as an intrinsic case: a special, significant example, not a typical or average case of how libraries implement scholarly communication outreach programs. I am interested in what is happening at the UMN, as Robert E. Stake says, "not because by studying it we learn about other cases or about some general problem, but because we need to learn about that particular case. We have an intrinsic interest in the case." ${ }^{5}$

\section{Positioning of the Researcher}

I carried out this research as a Ph.D. student in Antioch University's leadership and change program. I came to know Karen Williams, the first Associate University Librarian for Academic Programs at UMN, and her work there through her roles as founding faculty member and designer for the ARL/ACRL Institute on Scholarly Communication, member of ACRL's Scholarly Communication Committee, and member at large on ACRL's Board of Directors. I had heard Williams mention that UMN defined baseline expertise in scholarly communication for all librarians who serve as liaisons to disciplinary faculty members during the ARL/ACRL Institute on Scholarly Communication and observed the room of one hundred people, who were working on planning their own scholarly communication programs, begin to murmur with interest. It was clear that UMN is ahead of the curve in developing their program. Intrigued by their obvious commitment to change, I wanted to develop an understanding of ways liaison librarians at the UMN changed their primary responsibilities to include advocating for reform of the system of scholarly communication with faculty researchers and authors on their campuses. I seek to understand how they engage in furthering the goals of the outreach program and how they view these changes in their work.

\section{Key Conceptual Frameworks}

Systems thinking is a useful primary framework for examining a case like UMN with wide-scale change and participatory leadership. Distinct from linear thinking, systems thinking draws from physics, biology, and ecology, as well as nonscientific fields like music. A systems thinking approach recognizes the innate networks, the interconnectedness, interdependency, and collaboration among people in organizations. "It is not top-down or bottom up, but participative at all levels - aligned through common 
understanding of a system," ${ }^{\prime \prime}$ as Peter Senge describes it. He advocates viewing an organization as a system within systems and made up of systems as one of the five key practices to unleash the potential for organizational learning. ${ }^{7}$

Another proponent of systems thinking, Margaret Wheatley, explains, "the way life organizes itself is entirely different from the way humans have chosen to organize it, especially in modern day life. We are just beginning to understand this difference.... We do not have to move into these old patterns of organizing, which involve command and control, structure, and rules and policies as the way to create order. We have a choice." 8

Williams brought systems thinking practices, values, and beliefs to UMN from her time at the University of Arizona (UA) Library. Staff members at UA Library have used systems thinking for over a decade, writes Shelly E. Phipps. They view their workplace as "a laboratory of learning about organizational change" approach to prepare for "the transformational changes that will occur in the twenty first century." ${ }^{10}$ As this approach was applied, the UA Library goals "called for a flatter organization with shared decision-making and problem-solving responsibilities....As the non hierarchical approach took place, it was clear that all the embedded systems that had supported work in the former organization were incompatible with the new structure and goals."11 Phipps argues, "Culture change would not have been possible without systems change." ${ }^{12}$

Lee G. Bolman and Terrence E. Deal's Reframing Organizations ${ }^{13}$ provides a second framework for viewing this case. Within academic librarianship, there is acceptance and widespread application of their four frames - political, structural, symbolic, and human resources - in part as their book is the cornerstone text for the ACRL/Harvard Leadership Institute. Some particular assumptions of the symbolic frame have bearing in this case: "What is important is not what happens, but what it means" and "Activity and meaning are loosely coupled; events have multiple meanings because people interpret experience differently."14 As this case examines library liaisons as a group, one tenet of the symbolic frame is particularly noteworthy: "Example, not command, holds a team together." 15

Moving to the political frame, some relevant assumptions include, "Organizations are coalitions of diverse individuals and interest groups; there are enduring differences among coalition members in values, beliefs, information, interests, and perceptions of reality; most important decisions involve allocating scarce resources - who gets what." ${ }^{16}$ Both the symbolic and political frames are powerful in situations where there is a high level of ambiguity and uncertainty, where conflict and scarce resources are significant, and where organizations are working from the bottom up. ${ }^{17}$ This could well describe the situation facing many academic libraries today as we look to evolve in a tough economic climate.

\section{Methodology}

This case aims to develop an understanding of a culture and is, therefore, of an ethnographic style. To understand the changes at the UMN Libraries, my key method was semistructured in-person interviews with member checking in the form of brief follow-up phone calls and e-mails asking for clarification. I used open-ended interviews, described by Robert K. Yin as a common form of case study evidence, ${ }^{18}$ to gather information about the UMN change process from Williams and two liaison librarians affected directly by the new position description framework. These kinds of interviews, Yin says, "do not typically employ a structured questionnaire instrument but assume a more 'conversational' mode-requiring the investigator to have a sound prior knowledge of the subject matter if not about the specific person being 
interviewed." 19 I recorded notes from these conversations by hand, immediately typing them afterward to fill in gaps and to add my observations. The liaisons volunteered to participate based on an invitation forwarded on my behalf.

Since I carried out this research in my role as a student, the institutional review board of Antioch University fully vetted and approved of my research plan, participants signed consent forms, and, as part of member checking, they reviewed draft portions of my paper to ensure I did not misinterpret their comments or misrepresent the context. When I decided to adapt my work and submit a manuscript for publication consideration, I informed them and shared my final student paper for additional reaction. Williams offered me her express permission to use her name in this published report, and I created pseudonyms for the liaisons.

I supplemented the interviews and triangulated that data by drawing on documentation (such as reports, brochures, and Web sites). These additional sources of evidence provide context of the change process over time. Keeping in mind that this is an intrinsic case, I followed Stake's advice, "The more the case study is an intrinsic case study, the more attention needs to be paid to the contexts." 20

All three participants are involved in the libraries' scholarly communication planning group, and both liaisons support the sciences. As such, they are more knowledgeable of the issues and more invested in changing both the system of scholarly communication and the liaisons' roles than I would expect an average liaison to be. Without long-term field work, I relied on the information they provided to me and on their accounts of the events. In developing the case, I am filtering those stories yet again through my own lens and with my own bias.

\section{The Case}

\section{The Impetus for Systemic Change}

Arriving at the UMN Libraries in November 2004 from the UA Library, Williams encountered two different and very strong reactions from library staff members - "Thank God; we need to shake things up" and "We don't want any part of that" ("that" being team-based organization development and systems thinking). In many ways, the timing of her arrival was propitious.

Strategic change was transforming the libraries and the larger campus environment. Williams was recruited to lead a new library division, academic programs, to create close ties to academic life on campus, integrate library resources within academic programs, and contribute to the intellectual and educational missions of the university. Just a few months before Williams' arrival, the new university president introduced an ambitious strategic positioning initiative, "Transforming the U." 21 It sent the message that "upstarts with big ideas are not going to get trampled. For some people in the libraries, it freed them to take risks, for others it was a wake-up call that change is afoot on this campus and major change has support," Williams observed.

One of my participants, whom I'll call Pat French, observed, looking back, that University Librarian Wendy Lougee and Williams "changed the tone and changed the structure. One of the ways is by truly taking into account the realities of the university and its priorities. Wendy has done a marvelous job of raising the profile of the library, integrating the libraries' priorities to those of the university's. The library and its programs are much more vital now; they're exciting and evolving. Previously we were content; there was no risk taking."

With a university goal of becoming one of the top three public research universities in the world, and with the focus of the new division of academic programs, the UMN libraries set a priority to change their relationship to scholarly communication. 


\section{Introducing New Mental Models}

When Williams started, one of her first tasks was taking a hard look at how to structure the new division of Academic Programs, adding departments and adjusting staffing levels. Sitting in Williams' office, comfortably surrounded by a veritable indoor garden and an attractive array of photos and personal mementos, she reflects, "When I restructured, I had to pay attention to a lot of things. I'd had good exposure and training at Arizona-although nothing's perfect-to systems thinking and one of the gurus there was Peter Senge. To me it's essential to develop an understanding that we're part of the university and part of higher education."

Having written previously, along with Joseph M. Brewer and others, of a clear vision for how librarians can transform their own roles and contribute to the transformation of the colleges and universities they serve, ${ }^{22}$ Williams focused the energy of this new division on, among other things, integrating scholarly communication activities into the work flow of the liaison librarians by:

- $\quad$ establishing the Scholarly Communication Collaborative to support liaisons;

- changing liaisons' job descriptions;

- $\quad$ administering a self-assessment of knowledge, skills, and abilities; and

- requiring a performance goal around author rights.

While I will address each of these of four points in detail, Williams explains this multipronged approach thus: "People need more than just a vision and mission. You have to figure out your message and say it in every way and with multiple tools to reinforce it....You have to anchor change into the system, then celebrate success and celebrate failure. You have to reward risk taking."

\section{The Scholarly Communication Collaborative}

Williams created the Scholarly Communication Collaborative in fall of 2006 as a first major step in this change process. Believing that language is very important symbolically in signaling change, the word collaborative was selected because it has the implication that everyone participates. The Scholarly Communication Collaborative has "a two-pronged focus: develop and implement as appropriate a coordinated plan for the University Libraries to inform and educate its staff; and recommend appropriate approaches for engaging the campus community in the policy and practical issues that surround the process of scholarly communication." ${ }^{23}$

Founding members of the group, the first collaborative set up under the new organizational structure, had to make a big adjustment to this new way of working. One liaison says, "I had understood in my mind that it was more like a support group for those who are interested in these issues.... At the first meeting I saw the charge and time commitment, and it took me aback. It took time to be clear that the collaborative as a group would design and implement courses of action for others to take and could be entirely separate from the work I'd done before on these issues as a liaison."

The collaborative has sponsors who function like a steering committee to give guidance and feedback, remove barriers and provide resources. The sponsors decide the big overarching agenda for the year, like the current focus on author rights, while the chairs set the meeting agendas, run the meetings, report out, and design activities to achieve a goal. They check in through monthly meetings with the collaborative's cochairs and are tapped for resources to bring in speakers or help in communicating with liaisons.

Collaborative members support liaisons in two primary ways. First, they educate liaisons and foster discussion through workshops that may include external speakers. They also develop tools for liaisons like a self-playing presentation on author rights, a PowerPoint presentation template, talking points, and environmental scan exercises. ${ }^{24}$ 
The collaborative found that staff faced a steep learning curve. One liaison says, "It felt for awhile like we were having brown bags endlessly. Every time we'd have one, some liaisons would chime in to suggest other tools and more training.... It indicates a continuing lack of confidence about expertise and the general idea that since you're expecting me to do a new thing, you need to make it as easy as possible for me."

Even with this support, liaisons have to invest in preparing themselves before they talk to faculty. It's not just knowledge and preparation that's required, it is a deeper change in mindset-one that also requires opportunism. The second liaison to participate in this case, whom I'll call Julie Washburn, offered an example around author rights. "In every department there's a different hook, a different key. You have to think like a faculty member, 'Why do I care about this?' You have to find specific examples from their societies, their journals, and point out prohibitive language in agreements they actually would be signing. You have to be ready to go in. You can't put up the self-player and not know anything about their societies, their disciplines, their issues."

Bearing this in mind, the collaborative has developed structures to assist librarians in doing this kind of homework, like the two-stage environmental scan. For stage one, in fall 2007, liaisons gathered information based on what they already knew or could discover without interviewing or surveying faculty. Items include whether there is a disciplinary repository serving the field, major professional society/ies associated with the discipline, and the society's official position on open access. In the second stage, in spring 2008, liaisons interacted more directly with the department to identify influential faculty members, such as those who edit for journals or serve as officers in their disciplinary society. The stated goal of the environmental scan is to "help liaisons in their work with faculty on authors' rights issues and will also help identify faculty champions who can join with us in advocating for change in the scholarly communication system." 25

Another leadership challenge arises around shaping expectations and engaging liaisons when the collaborative has little direct authority. Collaborative members realized that language is important in how the cochairs convey information to the liaisons. For example, liaisons "are expected" to attend the workshops or complete the environmental scan but not "required." Who conveys the message is also important. Sometimes they ask Williams to send messages so that they carry more weight than a message from the cochairs would. The collaborative cannot, however, enforce compliance. The cochairs could, with things like the environmental scan exercise, inform Williams of those who have not completed the task and she could ask the department heads and supervisors to talk to the liaisons. As it turns out, there was a 97 percent completion rate of phase one, which revealed fascinating data that library administrators could use for other purposes in advocating for the library.

\section{Position Descriptions}

At the same time the collaborative was formed, the libraries were introducing a new framework for librarians to make position descriptions more uniform while, at the same time, allowing for flexibility and customization so that individuals could play to their strengths. The introduction to the internal, unpublished document reads, "Our profession faces significant change and this is reflected in the changing and expanding roles of librarians. The framework is intended to help articulate both ongoing and new roles and responsibilities." 26 Intentionally designed to bring people along with incremental changes over time, French observed, "Making the positions more similar could be viewed as mechanical, but it's also a way to change the substance of some jobs. If you didn't have liaison duties clearly spelled out before now you do. And it's not just the description on the paper that changes, but it's your job itself that is changing." 
Introducing position descriptions offered an important opportunity to integrate scholarly communication roles into liaison work. While the framework identifies roles and responsibilities in nine areas, those for scholarly communication are the following:

- educate and inform faculty, graduate students, and campus administrators about scholarly communication issues. Examples include:

- helping faculty and graduate students to understand their rights as authors; and

- contributing content to copyright and/or scholarly communication websites.

- advocate for sustainable models of scholarly communication.

- $\quad$ work closely with faculty and students to understand their changing workflows and patterns of scholarly communication; assist in the development and creation of tools and services to facilitate scholarly communication.

- $\quad$ support and promote the University Digital Conservancy by:

- helping administrators, faculty, and students understand the role of the UDC in building and preserving digital collections;

- $\quad$ working with faculty and departments to promote the UDC as a scholarly communication tool;

- assisting in content recruitment;

- identifying digital resources that require long-term preservation and merit sustained access; and

- helping to shape the infrastructure in which digital preservation and access can successfully evolve. ${ }^{27}$

Another tactic intended to show that the scholarly communication duties are not a separate, extra thing is leading by example. Some liaisons, like Washburn and French, are drawn to these issues and actively work with faculty and scholars on these issues anyway. Their model behaviors convey to other liaisons that they, too, should be carrying out these activities. For example, one of them wrote a rebuttal to an anti-open access editorial in a disciplinary society newsletter, and the editors published it. In a second success story, one liaison was invited by a faculty member to coauthor a chapter of a book. "I took that opportunity to work in a piece about the value of open access. That wouldn't have happened if I hadn't been having these kinds of conversations with faculty and didn't have the knowledge myself on these issues." While these two are motivated and engaged, French, at least, is doubtful that positioning this work as part of being a liaison resonates with others: "I don't know how successful it has been to frame it that way."

\section{Course Check}

Following on the collaborative's educational program and the institution of position descriptions, liaisons completed an anonymous self-assessment instrument on their knowledge, skills, and abilities (KSA) to carry out the work articulated in the revised position descriptions. It came after a year of education and intense activities to help librarians make these changes to their work. The KSA is an internal, unpublished instrument intended to help identify gaps and aid with future planning, not designed to be a statistically valid instrument.

The KSA survey asks librarians to rate their current knowledge, skills, and abilities in nine areas. A few of the statements for scholarly communication read:

- be aware of the scholarly communication differences among disciplines;

- possess a basic understanding of a variety of publishing models, including open access;

- understand the tenure process as it relates to publishing, including the issue of impact factor; 
- $\quad$ advocate for sustainable models of scholarly communication; and

- advise scholars on how they may manage the articles, preprints, and other materials that they gather. ${ }^{28}$

While the results were not yet aggregated when we spoke in February 2008, ${ }^{29}$ Williams mentioned that very few people said they were "advanced" in scholarly communication. She was surprised by how many said they fall into the basic and intermediate categories. "Now we'll have to go back to staff and discuss next steps. Any survey has its limitations, of course. And here it could be that 'Minnesota modest' thing where people tend to be overly humble in general. I believe people were very honest in completing this, but maybe they were too modest?"

\section{Performance Goal on Author Rights}

Another step in changing librarians' roles was implementing a performance goal in 2008 around talking to faculty about publishing agreements and retaining key copyrights. An important symbolic step, it indicates the organization is committed to a new model of operation. This new goal aligns with a broader systemic change; as Williams says, "This has really been helped out by the UMN endorsing the Committee on Institutional Cooperation addendum. This push for author rights is not just coming from me, the collaborative, or someone's department director. The Senate endorsed it; the Provost endorsed it." Although the goal is required, how one carries it out is flexible. It could mean a ten-minute presentation at a faculty meeting, talking to two people from the department over coffee, sending an e-mail message to spark an online dialogue, or leading a whole seminar.

Implementing this goal has required strong support from formal leaders. "Some departments are OK. Some department heads are strong and coach their people and are willing to be directive," Williams explains. "In others there is push back but not as much as I would have expected." She has taken personal responsibility for communicating her expectations. "I have made it clear that if a goal has to slide, it had better not be this one."

French, too, reports a mixed but generally positive response. She tells me about plenty of liaisons who are gung ho, like one who started a blog for her department on author rights issues since she could not meet in person with the faculty as a group (the department does not have regular meetings). Another liaison saw the beta version of the self-playing presentation and wanted to use it immediately. A third colleague finds it difficult in some respects to be a liaison and dislikes going out and talking to faculty. Yet this person gave presentations on author rights to two different departments. "It's good to see this progress," French says. "And it came about because the goal is enforceable, and we did provide the tools. Without scholarly communication as a priority, in the position description, in the goals, and without support from the collaborative, this wouldn't have happened."

Washburn also reported on the goal's effect on her own commitment to lead change in this area. While inclined to take on this work anyway, she says she now feels "absolutely compelled. It's in our formal goal statements." While she generally embraces scholarly communication responsibilities, "Probably there are liaisons who are resentful, who see it as very top down and an imposition. 'You will do this in your goals even though it's not your priority.' "

\section{What Liaisons Let Go}

When positions change, people feel they are being asked to take on more. Here, liaisons are explicitly expected to stop doing things in the areas of collection development, reference desk staffing, and departmental libraries. Liaisons must redirect scarce resources - their time-with inherent political implications. 
Approval plans were instituted; civil service staff were promoted to oversee information and reference desks and to function as supervisors of branch libraries. Williams approaches these changes gently. "I just start the conversation and understand that the first time it will be controversial and painful, but I also explain that we don't have to make a decision today or even in the first year. So the conversation continues, and when I'm not in the room it goes on. People come back to me with objections, and we discuss them. My job is to plant the idea, get the conversation going and make people a little uncomfortable. I keep saying, 'Could we do this differently? If we started over, what would it look like?" "

\section{Liaison Reluctance}

Williams has heard over and over from liaisons, "I can't do that! How do I make cold calls? What's my entré?" Indeed, many librarians are afraid of faculty and intimidated. Williams mused that while "librarians are often progressive politically and socially, they are not progressive in terms of changing and experimenting in their own work." In terms of risk taking, "we think about things as failure that probably aren't and avoid them in the future. If we want people to work in new ways they have to be comfortable hearing 'no' and feel that it's OK. How do you react? What would you do differently next time?"

Still, Williams remarks, "I'm surprised I haven't had more resistance. But our ways of doing things have really changed in the past five years. One reason, perhaps, that I haven't seen much resistance is because we're still doing some of the easier stuff, but what will it be like when it gets harder?" It may help that she talks up the UMN Libraries efforts in scholarly communication. "Positioning us as a national leader works to motivate staff. It's encouraging to them to think that people are watching us."

While shifting duties should be releasing time, from one liaison's perspective "it still feels like I'm expected to do everything. If we take it all on, there's not time to play to our strengths." And she discloses that many of her colleagues "still adhere to the old model.... There are many opportunities for everyone to come together, and you're supposed to be collaborating more and not isolated, yet there are still some people I never see." Yet, she reports, "There's a culture shift in the libraries. Now we have to work together across boundaries."

Some liaisons, particularly those in the humanities and even some in social sciences, seem to think that scholarly communication issues aren't terribly important, one liaison feels. "I get the sense from those librarians that they resent the scholarly communication initiative because they are being asked to do extra work. They feel this is a science issue, not their issue."

French spoke with evident frustration about foot dragging by some liaisons. Her voice shook a bit as she declared, "Plenty of people think it's no problem that they don't feel knowledgeable about scholarly communication; it's not their own issue, or it's a lesser obligation. But we don't think that way about other liaison responsibilities. It's not OK to think, 'Oh well, I just don't know much about the subject index in my field.' No one would think it's fine to have that attitude, but with the scholarly communication issues somehow it's OK?"

Another factor playing into the reluctance to take on new responsibility is the traditionally autonomous nature of the liaison librarian position. French explains,

While everyone has a huge mix of duties, they also have their own agendas. To a large extent the jobs lend themselves to choosing to spend more time on selecting books or on reference if that's what you want to do. Sure, scholarly communication duties are now written into a job description, but people still choose to 
spend time on what interests them. So while scholarly communication is stated as a priority with goals and follow up, some people's internal priorities are not in line necessarily. Even though it's spelled out and they don't refuse to do it, they don't think it's an important part of their job.

\section{Looking to the Future}

While total transformation remains on the horizon, French says, "I recognize and admire the implementation of this change around scholarly communication duties and responsibilities at the library. This has been a gradual process with implementing goals in general, changing the position descriptions, and integrating author rights into our performance evaluation process. Now all the parts reinforce each other. There were statements from Karen, reinforcement through supervisors and outside speakers. In fact, now we're using the same model with information literacy." She finds the libraries' new directions, by focusing on scholarly communication, to be quite promising:

It's very interesting the relationships we're developing within the university. By having one group, the library, that pays attention to these issues and is trying to get the word out, it means we are assuming a leadership role in our university. And we're getting a good response. Take the recent National Institutes of Health mandate [to make results of research it funds publicly accessible in PubMed Central]. The Vice President of the Research and Grants Administration Office approached the libraries to collaborate on implementation. That's big. Some of the issues we're talking about, like author rights, don't have any other home on campus. I hate the conversation that the library has to reinvent itself to stay relevant. It's a very different thing to say we recognize a need on our campus and are proactively doing things to fill that need. It puts us in a very different relationship.

Washburn sees the future of the system of scholarly communication in flux and evolving and a need for librarians to understand and convey the nuances:

People want to hurry it along, and get changes in the system quickly, but we can't. I think we can't come at faculty saying "we want you to advocate for us on position $X$," like "everything needs to be open access." It's not that easy, and we can't ride roughshod over their issues. We still don't know what model we'll land on or what combination of models we'll land on. It's not so clear cut that we'll just convert fee-based access to open access. There could be all kinds of combinations. We understand scholarly societies need to protect their revenue stream and are fine with embargoes. We need to see more experimentation and to test out more publishing models.

For Williams, the self-directed, autonomous nature of librarianship has to change for academic librarians to remain viable in the future.

My take on our profession is that we've done fairly well for ourselves. Prior to the last decade we had it pretty easy. We were independent, could decide how we wanted to spend our time and what we wanted to do. Some people think that's how it should be on a day-to-day basis still, and I respectfully disagree. Part of this attitude in some institutions is related to librarians who hold tenure. But we have a service to run. This has really challenged my way of thinking on librarians being part of the tenure process. We've changed, and it's not about collections anymore; we have to work together to provide services. It can't be that a library, 
a department, or a campus receives the service that a particular librarian feels like providing. Going forward it's very dysfunctional for librarians to think they get to choose what they get to do.

\section{Analysis and Interpretation}

As Stake espouses, when describing case study research, "Given the intense interaction of the researcher with persons in the field and elsewhere, given a constructivist orientation to knowledge, given the attention to participant intentionality and sense of self, however descriptive the report, the researcher ultimately comes to offer a personal view." 30

To my eyes, the changes underway at the UMN Libraries are remarkable. Through the Scholarly Communication Collaborative and the many other efforts, the libraries' positional leaders are sending a clear message that librarians and librarianship must change dramatically to remain viable. Individuals cannot be autonomous in setting their own priorities or remain isolated in the library any longer. They must talk to faculty regularly and be an active part of the academic life of the campus; it is not something reserved for the university librarian.

Collaboration and systems thinking are at the heart of these changes. It is no small move to go from thinking of "self" as an individual who is competent and secure in one's own knowledge and skill set (with the inherent competitive and hierarchical implications that mindset brings) to being part of a "system" that is in flux and evolving. Cooperation is a core competency, and librarians must think of the many systems of which they are part-higher education, teaching and learning, research, scholarly communication, the academy, the university, the local community, and so on. To echo one liaison, there is indeed a culture shift underway at the UMN Libraries. Such an endeavor takes time and a commitment to sustaining the effort.

This level of change takes strong support and dedicated leadership from administrative leaders and shared power with the liaisons themselves. This change is happening through a multipronged approach, where all parts reinforce each other. It is not enough to add duties to a job description or a goal in a performance appraisal. The collaborative of peers is essential, giving concrete expectations to, and support for, liaisons. Likewise, the sponsor model appears very effective. Library leaders have a high tolerance for risk, encourage experimentation, and readily allow failure.

While Williams is a strong practitioner of systems thinking, there are some traditional command and control methods in place. The changes are not organic or ground up; they are being driven from the top down. Changes to the job description and performance goal are fairly aggressive. Through measures like these, you can get compliance, but this does not necessarily equal commitment. Lack of commitment is reflected in the reluctance from some liaisons. Even the two liaisons who spoke to me, among those most committed to change in scholarly communication, described some aspects of their experience with a good deal of tension and discomfort. To gain commitment, people must participate in creating the new, as participation increases the likelihood that change will stick. Many liaisons, it seems, are content to be passive and do not participate in these new endeavors.

Liaison librarians are both adopting a new skill set-advocacy and persuasion - and developing a new knowledge base around the system of scholarly communication. These are two very substantial endeavors. Either change alone would be quite significant. Williams infused her comments with energy, optimism, and confidence in liaisons' abilities to become advocates and develop skills of persuasion. Investing in learning the issues of scholarly communication requires conviction that these are the right issues and this is the right time. Through their work on the collaborative, French 
and Washburn show this dedication and demonstrate their certainty that these issues are core to the profession.

Implementing such large-scale change requires everyone involved to redirect resources and make decisions that are political in nature. So liaisons are asked to loosen their ties to the activities that traditionally defined them as librarians. This puts them at a crossroads of competing values. They wonder, "What happens if I turn my back on the collection, the reference desk, my departmental library? Who am I anymore?" This is a major shift in mental models about what it means to be a librarian in the twenty-first century. It requires one to come to terms with the changes, let go, and reorient oneself. Understandably, some fear the loss of competence.

As a profession, librarians often feel faculty members have impressive credentials and are somehow superior. This mindset poses a significant challenge for creating an atmosphere of mutuality and shared action to change such a large system as scholarly communication. Librarians have to think differently about themselves as partners with faculty in the research enterprise and not servants. I wonder if, as U.S. society continues to become less formal, as hierarchy breaks down, and titles mean less, librarians will be less "scared" of faculty members. Perhaps this is naive, as the academy still retains the prestige economy model-ranking journals, scholars, and institutions. However, just as the scholarly communication system is changing, we see calls to transform the basic underpinnings of the academy. Tenure reform, the rise of the portfolio career, revolutions in pedagogy, the push for lower tuition, and increased calls for accountability all signal a sea change ahead for higher education.

\section{Conclusion and Discussion}

In examining these changes in scholarly communication at the UMN Libraries, I can see real implications for leadership and change in the profession of librarianship at large. At the same time, I want to acknowledge that this case is unique to its own context. I chose to examine the UMN because I held an intrinsic interest in this particular case, and as such the implications are heavily context dependent. This is an organization that has been intentionally implementing a change process, incorporating new roles for liaison librarians and shifting mental models.

There are many factors contributing to the interconnected system that is the UMN Libraries. As such, I cannot claim generalizability of any of my findings, although I do propose transferability. The implications that point to the value of systems thinking and reinforcing the message of change from many angles may well serve others. These could be transferred to similar programs at other academic libraries, with care. For instance, some of the most striking features of UMN's change process are the following:

- $\quad$ the fresh perspective Williams brought as a relative newcomer;

- the large investment in learning, iterative processes, and communication loops with collaborative members, sponsors, and administrators sharing responsibility;

- an environment that rewards risk taking, as with the author rights performance goal, and provides tools and support to those taking risks;

- the need to be clear and directive (for example, in the job description framework); and

- the value of encouraging reflection, through the KSA, so that liaisons better understand themselves and where to focus on their future development.

Other libraries seeking to develop programs for working with their liaison librarians to own fully scholarly communication reform might want to consider these steps:

- encouraging democratic involvement of a wide group of stakeholders to increase a sense of ownership and ultimately create more commitment; 
- $\quad$ using a systems thinking approach to plan and implement a multipronged program that is integrative and change-centric;

- being explicit about the context for the change effort and intentional in articulating it as core to the evolving nature of our profession, an important step symbolically for making meaning;

- $\quad$ sharing frequent updates to disclose the reasons behind changes, to show how they are related, and to solicit feedback; and

- $\quad$ using a political lens to build coalitions outside the library and promote mutuality over a potentially polarizing dynamic with sensitive topics like open access or promotion and tenure.

It would be interesting to revisit UMN Libraries in three years and see how they are doing, particularly with engaging humanities liaisons. As an organization intentionally implementing a change process, it would be equally interesting to know how and if shifts in the external environment, such as the economic downturn, have affected the libraries' planned change. And, recognizing the interconnected nature of change, what will come from these early experiments and initial risks? Will there be great evolutionary leaps in the UMN scholarly communication outreach program in future years?

Future researchers may wish to consider questions related to the perspectives of newer librarians. Will librarians now entering the profession more readily embrace scholarly communication duties and the mindset that sees this as core to the profession? Is this true regardless of generation, or are there nuances among age groups? Other questions are worth exploring as technology enables a more robust informal system for scholarly communication. Will this informal system, aided by social networking tools where scholars communicate peer-to-peer, eclipse the importance of formal publishing for evaluating and disseminating knowledge? If so, what are the implications for libraries?

The changing system of scholarly communication offers librarians exciting, important, and engaging ways to become a vital part of the academy. Librarians at the UMN are probably not so different from other librarians, and their faculty not so different from other faculty, in terms of the attitudes, concerns, beliefs, and values they hold. A unique confluence of events at the UMN made the climate just right for Williams' arrival and supported the level of sweeping change she initiated.

\section{Notes}

1. I am indebted to members of the ACRL Scholarly Communications Committee, in particular Lee Van Orsdel, for first articulating and defining this concept of mainstreaming.

2. Association of College and Research Libraries Scholarly Communications Committee, "Principles and Strategies for the Reform of Scholarly Communication" (Association of College and Research Libraries, June 2003). Available online at www.acrl.org/ala/mgrps/divs/acrl/publications/whitepapers/principlesstrategies.cfm. [Accessed 18 March 2008].

3. Kathleen A. Newman, Deborah D. Blecic, and Kimberly L. Armstrong, Scholarly Communication Education Initiatives SPEC Kit 299 (Washington, D.C.: Association of Research Libraries, 2007). Available online at www.arl.org/bm doc/spec299book.pdf.zip. [Accessed 18 March 2008].

4. See endnote \#1.

5. Robert E. Stake, The Art of Case Study Research (Thousand Oaks, Calif.: Sage Publications, 1995), 3.

6. Peter M. Senge, The Fifth Discipline Fieldbook: Strategies and Tools for Building a Learning Organization (New York: Currency, Doubleday, 1994), 89.

7. Ibid., 5-12.

8. Margaret Wheatley, "A New Paradigm for a New Leadership," in Reflections on Leadership, ed. Richard A. Couto (Towson, Md.: University Press of America, 2007), 106.

9. Shelley E. Phipps, "The System Design Approach to Organizational Development: The University of Arizona Model," Library Trends 53, no. 1 (Summer 2004): 68. 
10. Ibid., 68.

11. Ibid., 72.

12. Ibid., 72 .

13. Lee G. Bolman and Terrence E. Deal, Reframing Organizations: Artistry, Choice, and Leadership (San Francisco: Jossey-Bass, 2003).

14. Ibid., 242.

15. Ibid., 289-90.

16. Ibid., 186.

17. Ibid., 310 .

18. Robert K. Yin, The Case Study Anthology (Thousand Oaks, Calif.: Sage Publications, 2004), 179.

19. Ibid., 179.

20. Stake, The Art of Case Study Research, 64.

21. University of Minnesota, Transforming the $U$. Available online at www1.umn.edu/systemwide/strategic_positioning. [Accessed 18 March 2008].

22. Joseph M. Brewer, Sheril J. Hook, Janice Simmons-Welburn, and Karen Williams, "Libraries Dealing with the Future Now," ARL: A Bimonthly Report on Research Library Issues E Actions, no. 234 (June 2004): 1-9. Available online at www.arl.org/bm doc/dealing.pdf. [Accessed 16 March 2008].

23. University of Minnesota Libraries, Scholarly Communication Collaborative Home Page. Available online at https://wiki.lib.umn.edu/ScholarlyCommunicationCollaborative/HomePage. [Accessed 18 March 2008].

24. Many of these tools are publicly available from the Collaborative Home Page, Liaison Tools. Available online at https://wiki.lib.umn.edu/ScholarlyCommunication/LiaisonTools. [Accessed 18 March 2008].

25. Collaborative Home Page, Environmental Scan for Scholarly Communication - Part One. Available online at https://wiki.lib.umn.edu/ScholarlyCommunication/SurveyPartOne. [Accessed 18 March 2008].

26. University of Minnesota Libraries, Academic Programs, Librarian Position Description Framework.

27. Ibid.

28. Ibid.

29. For more on the KSA process at the U of MN Libraries, see chapter by Stephanie Horowitz and Janice Jaguszewski expected in the forthcoming book: The Expert Library: Staffing, Sustaining, and Advancing the Academic Library in the 21st Century to be published by the Association of College and Research Libraries.

30. Stake, The Art of Case Study Research, 42. 